\title{
Plastination of Plexuses Brachialis, Lumbosacralis And Cauda Equina Using In Education Of Neuroanatomy Of The Goat
}

\author{
Basset Aly AE*, Seleem AA and Mohamed Sh Kh \\ Plastination Unit, Department of Anatomy and Embryology, Faculty of Veterinary Medicine, \\ Zagazig University, Egypt.
}

* Director of Plastination Unit

\begin{abstract}
Plastination of nervous tissue has become a very important tool in teaching neuroanatomy. Also, plastinated nervous specimens can be used to study the anatomical relations in clinics right before surgical operations.

The aim of using plastinated models is to increase knowledge, understanding as well as imagination of students about the complex anatomical parts of the central nervous system. The plastinated anatomical teaching model of Medulla spinalis, Plexus brachialis, Plexus lumbosacralis and Cauda equina of goat displays a clear morphology that corresponds qualitatively to the actual cadaver specimens.
\end{abstract}

Apparently healthy four goats (ten months age) from native breed were used. Goats were subjected to silicone S10 plastination technique. Prior to plastination, the goat was prepared by injected via $\mathrm{I} / \mathrm{V}$ by Xylazine $\mathrm{Hcl}(0.01 \mathrm{mg} / \mathrm{kg})$, cutting Arteria carotis communis for complete bleeding, and injected via the latter artery with $10 \%$ formalized solution then immersed in the same solution for at least four weeks. Medulla spinalis and attached peripheral nerves, Plexus brachialis, Plexus lumbosacral and Cauda equina were dissected.

The present study provides enhancement for the teaching of the neuroanatomy of the goat in our department. Particularly, Medulla spinalis, Nervi cervicales, Plexus brachialis, Nervi thoracici, Plexus lumbosacralis and Cauda equina were selected as learning models in special unit in the department and provide a plastinated model to study the anatomy of this system. Understanding of the anatomy of the nervous system is important not only for veterinary students but also for veterinary doctors while undertaking surgery on that plexuses and nerves.

\section{INTRODUCTION}

Principles of silicone plastination techniques are in use in many institutes all over the world. This is due to various factors as easy to learn, low starting costs, easy obtainable equipment.

The application of S10 on the study of the central nervous system is useful for teaching a short and intense portion of the freshman anatomy course, with deep understanding of concurrently with neurophysiology and neurohistology at our institution. The increasing of understanding of neurophysiology makes it more desirable that students be familiar with basic neuroanatomical structures. Hence the student is better prepared to integrate and understand these neuroanatomical structures which may be affected solving in certain neurological problems (1).

On the other hand, it becomes possible to build a "library" for teaching and research using 
plastinated tissue specimens without shelf upon shelf of alcohol and formalin filled jars as developed by (2). The obtained specimens are dry, well preserved, last indefinitely, odor free, durable. However, this is depending on the tissue, concerning its flexibility and retains adequate color differentiation. The plastination process may be used for almost any animal or human tissue of almost any size.

The use of plastinated tissues in the neurosciences will greatly facilitate such tasks as teaching neuroanatomy, lab procedures (without repetitive use of live animals) and other tasks requiring the visualization of Systemae nevrosum centrale et periphericum either in situ or removed from the body (1).

In the new Current Plastination Index (3), nearly $30 \%$ of the articles and preservations on plastination deal with plastination in the neurosciences. Thus it appears that the most important applications of plastination may be in the neurosciences.

\section{MATERIALS AND METHODS}

Apparently healthy four goats (10 months age) from native breed were used. Goat was constructed the plastination technique; goat was injected I/V by Xylazine $\mathrm{Hcl}(0.01 \mathrm{mg} / \mathrm{kg})$ (4). Many steps were considered in order to prepare plastinated anatomical learning model of nervous system of the goat:

\section{Specimen Preparation}

Selection of a suitable cadaver might assure a better specimen, the goat should be of small age not be over than 1 years. Since skull and the spinal cord was easily crushed.

Goat was injected via Arteria carotis communis with $10 \%$ formalized solution. Injected goat was immersed in $10 \%$ formalin solution for at least four weeks to be used in the following preparations:
Preparation of an anatomical teaching model of Medulla spinalis $(5,6)$ :

Dissection of spinal cord was done from a dorsal approach of the formalized goat; first, the vertebral canal was sawed open with an oscillating saw. The blade of the oscillating saw was angled near the vertebral body, proceeding linearly, taking care not to damage the spinal nerves; the pedicles were transected exposing the intervertebral foramina. It was important to control the depth of cut and thus prevent damage to the cord and roots.

If the blade did not cut deep enough, the intervertebral foramina were not reached. So, once the pedicles were transected, the dorsal part of the spine was removed starting from the cervical region. The transection is proceeded to intervertebral foramina in the lumbar region keeping each spinal nerve emerged laterally as it through the dura mater.

Similarly, from the sacral region to the lumbar region, the dura mater was sectioned in the in situ fixed specimen.

Preparation of Nervi spinales, Plexus brachialis, Plexus lumbosacralis and Cauda equina samples:

Nervi spinales periphericum of the goat were loosely dissected in cervical, thoracic, lumbar and sacral regions as well as fore and hind limbs. Also, the spinal nerve roots which shared in the formations of Plexus brachialis, Plexus lumbosacralis and Cauda equina were appeared. Furthermore, connections of spinal nerve roots with sympathetic chains were dissected.

The constituted portions of nervous system of goat were coated completely with gauze (added step) and it was fixed into a previously prepared $10 \%$ formalin solution for 4 weeks.

Plastination process: the most common method and the one which was used here was the silicone impregnation method, also known as, ("S10" method), four main steps were carried on (7). The latter steps were performed in the S10 room of Zagazig Plastination Laboratory (Plate. 1). 


\section{Fixation}

The prepared specimen was fixed for at least four weeks in $10 \%$ formalin and placed in a cold room $\left(3-5^{\circ} \mathrm{c}\right)$ (this stabilized the tissue and prevented autolysis). After the fixation was completed, the specimen was rinsed by running tap water for about 12 hours before the next step.

\section{Dehydration}

The prepared fixed specimen was dehydrated form water and lipids by a process known as "Freeze Substitution" using acetone; where the recommended ratio of specimen weight to volume of acetone was 1:10. The specimen was placed in a closed bath containing a cold $-25^{\circ} \mathrm{C}$ acetone $(80: 95 \%$ acetone) for about 4 weeks. The specimen was gradually shifted weekly from $80 \%$ to $85 \%$ to $90 \%$ to $95 \%$ acetone concentration. Daily stirring was essential to prevent trapped air bubbles on the inner surface of the specimens and to accelerate dehydration.

Monitoring of acetone concentration (using acetonometer) was carried out daily until measurements taken for three successive days remained stable at $95 \%$. This stable concentration of acetone indicated that the dehydration process was completed.

\section{Forced Impregnation}

The dehydrated specimen was submerged into the liquid polymer mixture (5). The polymer mixture consisted of 100 part of Biodur S10 "polymer or silicon" resins was mixed well with one part of Biodur S3 "the polymerizing agent or hardener". Then specimen was placed in vacuum and freezing conditions $\left(-25^{\circ} \mathrm{C}\right)$. The vacuum drew out the acetone from the specimen, leaving the polymer in its place. This step duration is about 4 weeks.

The specimen was removed from the impregnation bath and placed on racks for 2 days at room temperature to drain excess of polymer from the specimen. A towel was used to remove the excess polymer from specimen's surface after removal of surrounding gauze, until surface became clean and just sticky.
The specimen was mounted on a horizontal wooden platform (painted black) measuring $150 \mathrm{~cm}$ long and $75 \mathrm{~cm}$ wide. Wax and plastic fixers were used for fixation of the dissected nervous skeleton to the wooden plate.

\section{Gas Curing}

Next, the polymer filled specimen was placed into a sealed chamber where it came into contact with a curing gas (8). This gas hardens the polymer making the specimen dry to touch in about 48 hours.

The specimen was placed at room temperature in a closed chamber. The latter contained a flask with a small amount of Biodur gas cure solution "S6". The exposure of the specimens to the S6 gas inside the chamber caused hardening of the polymer, first at the surface and later through out the depth of the specimens. When humidity in the working place was high, a flask containing calcium chloride was used to absorb water to prevent the precipitation of white silicate salt on the specimen's surfaces. Curing step is usually completed within 2-7 days.

For final cure, specimen was placed in a tightly sealed plastic bag to permit the S6 gas trapped in surface layer to diffuse slowly towards the deeper layer of the specimen to ensure complete curing of the entire specimen. This step required 4 weeks.

A survey was applied out to influence a safety recent method of preservation of tissues which is plastination and how this technique accepted among the students. A sample of group of students was taken from (freshmen and second year) students of the anatomy department, Faculty of Veterinary Medicine of Zagazig University of Egypt. The plastinated specimens and formalinized specimen were introduced together in one binge for the students, according to (9).

The Nomenclatures were used along the course of this work were adopted by (10) which prepared by the International Committee on Veterinary Gross Anatomical Nomenclature (I.C.V.G.A.N.). 


\section{RESULTS}

The present study focuses on the main application of plastinated nervous tissues for teaching neuroanatomy. Plastinated spinal cord serves in determination of origins of spinal nerve roots, spinal plexuses and termination of spinal cord as shown in (Plate. 2/A).

The nervous tissues and vertebrae (Plate. 2/A) demonstrate that bony as well as soft tissues can be plastinated. Indeed, plastinated bone resists shrinkage than that of nervous tissues. The shrinkage of spinal cord after plastination is little increased than that of vertebral column.

Plate (2/A) illustrates some of the desirable qualities, quite realistic and excellent specimen for displays of this plastinated nervous teaching model. Medulla spinalis of the goat display flexibility yet are rigid while fixed on the floor of vertebrae. The plastinated nervous system of goat (Plate. 2/A) clearly demonstrates parts of the nervous system (Medulla spinalis, Nervi cervicales, Plexus brachialis, Nervi thoracici and Plexus lumbosacralis).

Nervi spinales cervicales and Medulla spinalis Pars cervicalis (Plate. 2/B), were clear, some what flexible and easily handled. The dorsal and ventral branches are easily demonstrated thus making the specimen useful for teaching normal or formalized anatomy. Nervi spinales cervicales (1-8) and Plexus brachialis dextra et sinistra are clearly observed. The origin of $N$. phernicus from union of ventral branches of sixth, seventh and may be fifth cervical nerves can be also seen (Plate. 2/C).

Plexus brachialis dextra et sinistra of the goat (Plate. $2 / C \& D)$ show very important and excellent specimen for display in practical anatomical sessions which enable students to identify the origin and how Plexus brachialis is formed. The parts of brachial plexus in (Plate. $2 / C \& D)$ are individually identified, as it is formed from ventral branches of seventh, eighth cervical nerves and first thoracic spinal one.
Nervi spinales thoracici and Medulla spinalis Pars thoracica of the goat (Plate. 3/A) are plain, and its origins from the spinal cord are well preserved. From the second to the thirteen Nervi spinales thoracici are plainly visible. Also their dorsal and ventral divisions are clearly demonstrated. (Plate. 3/B\&C) provides a clear plastinated dissected specimen, showing Truncus sympathicus runs under the ventrolateral aspect of thoracic vertebrae with its communications with the roots of thoracic spinal nerves.

Nervi spinales lumbales et sacrales (Plates. 3/D and 4/A) forming the Plexus lumbosacralis; Origins of Nn. iliohypogastricus, ilioinguinalis, genitofemoralis, femoralis, obturatoricus et ischiadicus are very similar in arrangement to formalized ones, though its texture are much firmer than either fresh or formalized specimens.

Preparation of specimen of Plexuses lumblis and sacralis with its branches is indeed time-consuming, however very accurate as shown in (Plate. 4/B, 4/C and 4/D), but the resulting specimen is very useful in improving mental thinking and understanding of students. We can recognize much firmer nerves than fresh or formalized tissue such as Nn. iliohypogastricus, ilioinguinalis, genitofemoralis (Plate. 4/A), femoralis, obturatoricus, glutaeus cranialis, ischiadicus, glutaeus caudalis et pudendus. (Plate. 4/B, 4/C and 4/D) and sacral and caudal nerves (Plate. 4/C).

Cauda equina of the goat (Plate. 4/B and $4 / C$ ) is splayed prior to curing to readily differentiate the different nerves. A Little shrinkage in Medulla spinales happens, leading to little backward movement of Conus medullaris. Termination of spinal cord between last lumbar and first sacral vertebrae (just before the first sacral) is easily recognizable. Also, Filum terminale of dura mater and $\mathrm{Nn}$. caudales are plainly seen. Thus, the latter is very useful for applications of posterior epidural anesthesia of the goat through determining the site of injection in epidural space. 
Finally, the prepared anatomical plastinated models of nervous skeleton were collected in a small unit as described by (11). Also, all of the images of the study were inserted in the window of presentation as JPG file format to be included in teaching computer $\mathrm{CD}$, added in the same unit. Thus unit was constructed in anatomy museum of my department, Faculty of Veterinary Medicine, Zagazig University.
The collection of student opinions about plastinated specimens express that most of students accepted the plastination as a learning method, little of students not accepted, some of students prefer combination between the traditional and plastinated methods and others students noted that plastinated specimens will be very useful in self studying at the home through keeping it. 


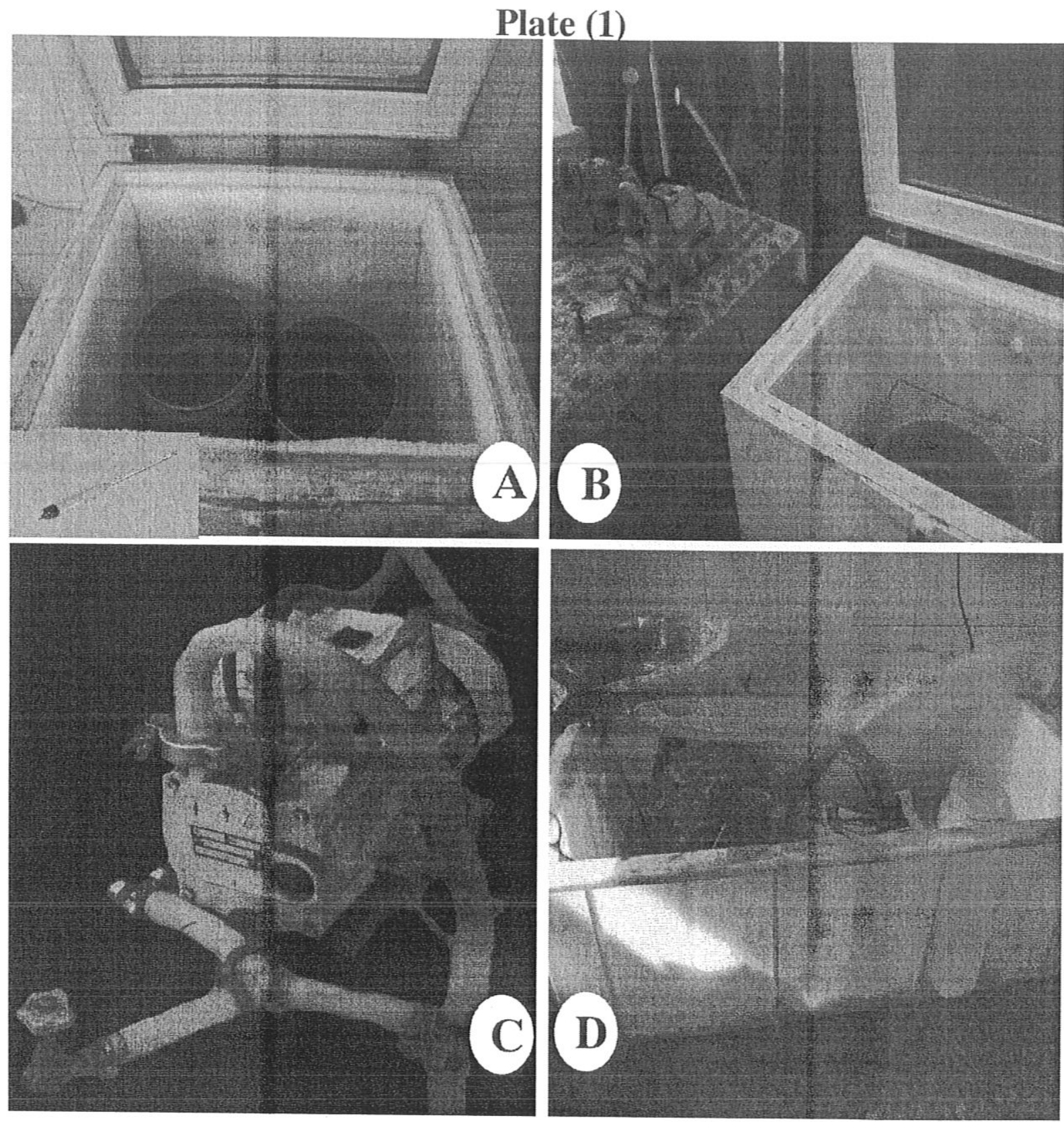

Plate (1)

A. A photomacrograph of S10 room of Zagazig Plastination Laboratory showing Freezer for acetone recovery containing two dehydration panels and an acetonometer using in the step of dehydration of the latter fixed specimens.

B. A photomacrograph of S10 room of Zagazig Plastination Laboratory showing Plastination freezer containing plastination kettle which connects with vacuum pump and a monitor using in the step of forced impregnation of the latter dehydrated specimens.

C. A photomacrograph of S10 room of Zagazig Plastination Laboratory showing vacuum pump using in the step of forced impregnation of the latter dehydrated specimens.

D. A photomacrograph of S10 room of Zagazig Plastination Laboratory showing a simple hardening unit using in the step of curing of the latter polymer filled specimens. 

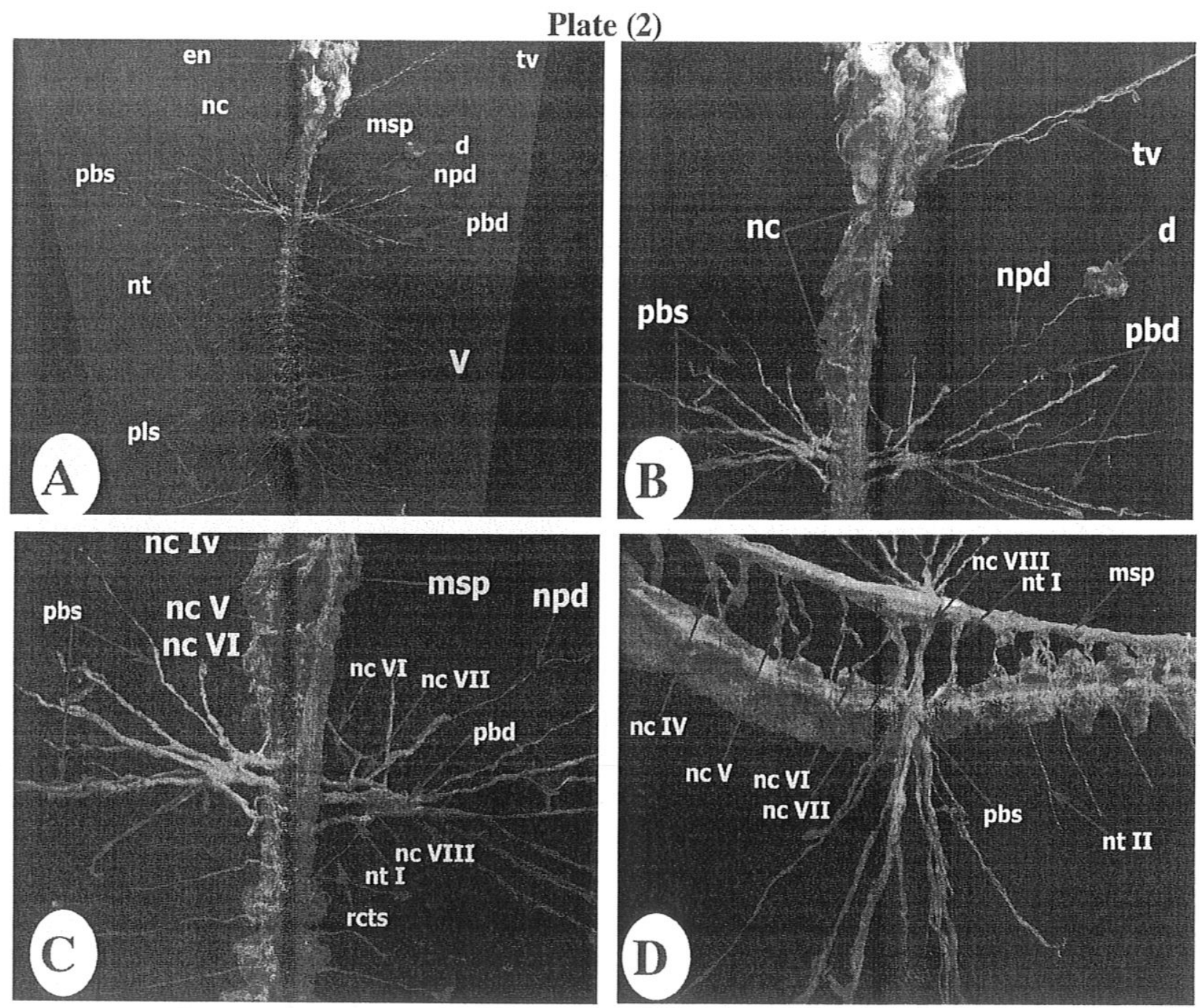

A. A photomacrograph of plastinated anatomical teaching model of the nervous system of the goat after opening the cranial cavity and vertebral column from skull to last caudal vertebrae (fixed on a wooden plate) (dorsal view) showing Encephalon (en); Medulla spinalis (msp); Truncus vagosympathicus dexter et sinister (tv); Nervi spinales cervicales (nc); Plexus brachialis dextra (pbd); Plexus brachialis sinistra (pbs); N. phrenicus dextra (npd); Diaphragm (cutted)(d); Nervi spinales thoracici (nt); Vertebrae (V) and Plexus lumbosacralis (pls).

B. A photomacrograph of plastinated anatomical teaching model of the nervous system of the goat after opening vertebral column (fixed on a wooden plate) (neck region from 1-7 cervical vertebrae) (dorsal view) showing Nervi spinales cervicales (nc); Truncus vagosympathicus dexter et sinister (tv); Plexus brachialis dextra (pbd); Plexus brachialis sinistra (pbs); N. phrenicus dextra (npd) and Diaphragm (cutted)(d).

C. A photomacrograph of plastinated anatomical teaching model of the nervous system of the goat after opening vertebral column (fixed on a wooden plate) (neck \& thoracic regions from 5 cervical to 3 thoracic vertebrae) (dorsal view) showing Medulla spinalis (msp); N. spinalis cervicalis IV (nc IV); N. spinalis cervicalis V (nc V); Ramus ventralis nervi cevicalis VI (nc VI); Ramus ventralis nervi cevicalis VII (nc VII); Ramus ventralis nervi. cevicalis VIII (nc VIII); Ramus ventralis nervi thoracis I (nt I); Plexus brachialis dextra (pbd); Plexus brachialis sinister (pbs); N. phrenicus dextra (npd) and Ramus communicans cum truncus sympathicus (rcts).

D. A photomacrograph of plastinated anatomical teaching model of the nervous system of the goat after opening vertebral column (fixed on a wooden plate) (neck \& thoracic regions from 4 cervical to 5 thoracic vertebrae) (lateral view) showing N. spinalis cervicalis IV (nc IV); N. spinalis cervicalis V (nc V); Ramus ventralis nervi cevicalis VI (nc VI); Ramus ventralis nervi cevicalis VII (nc VII); Ramus ventralis nervi cevicalis VIII (nc VIII); Ramus ventralis nervi thoracis I (nt I); Plexus brachialis sinister (pbs); N. spinalis Thoracis II (nt II) and Medulla spinalis (msp). 
Plate (3)
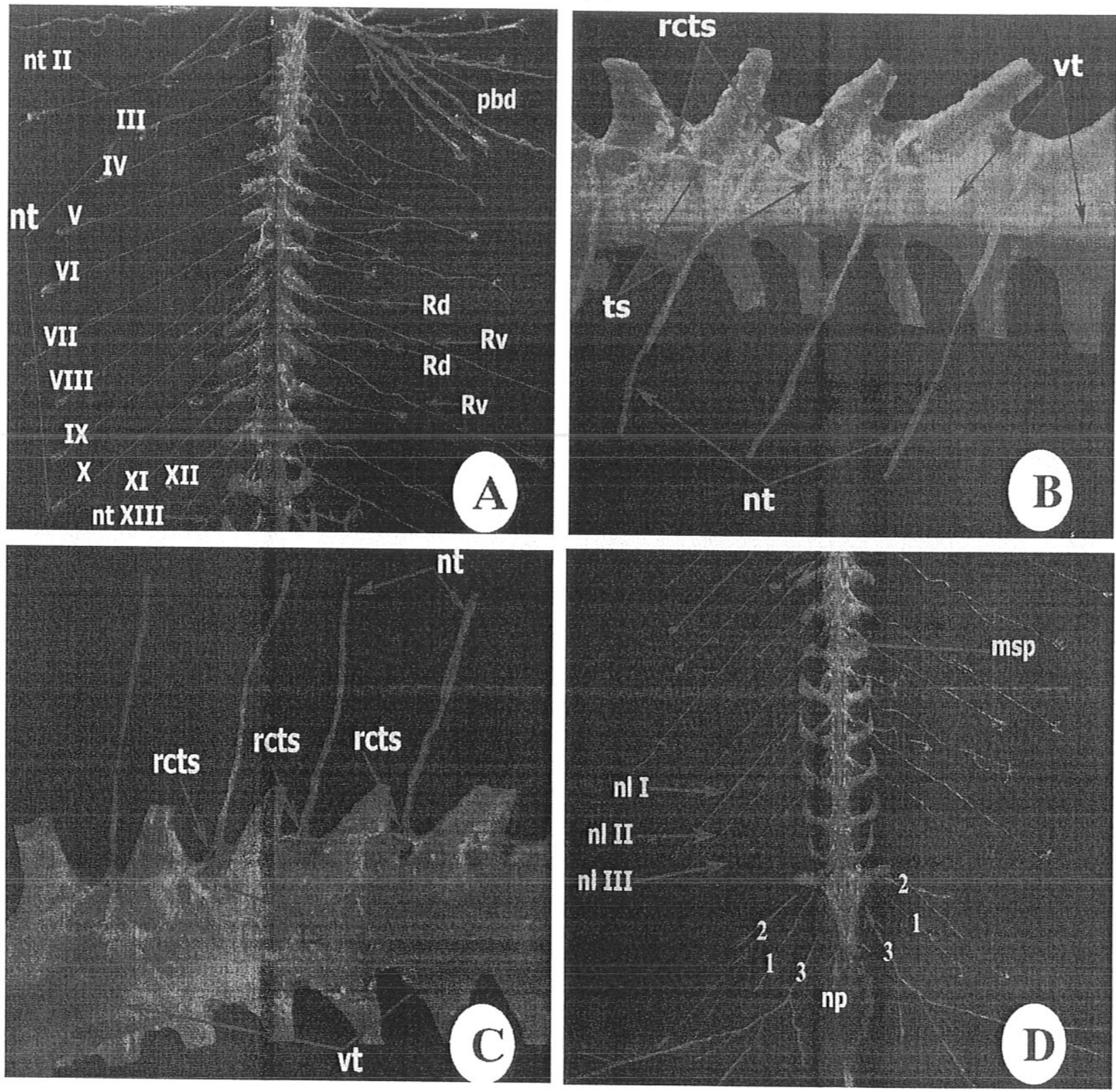

A. A photomacrograph of plastinated anatomical teaching model of the nervous system of the goat after opening the vertebral column (fixed on a wooden plate) (thoracic region from 1 thoracic to 1 lumbar vertebrae) (dorsal view) showing Nervi spinales thoracici (nt); N. spinalis Thoracis II (nt II); N. spinalis Thoracis XIII (nt XIII); Rami dorsales (Rd); Rami ventrales (Rv) and Plexus brachialis dexter (pbd).

B. A photomacrograph of plastinated anatomical teaching model of the nervous system of the goat (thoracic region from 9 to 12 thoracic vertebrae) (ventrolateral view) showing Truncus sympathicus (ts); Ramus communicans cum truncus sympathicus (rcts); Nervi spinales thoracici (nt) and Vertebrae thoracicae (vt).

C. A photomacrograph of plastinated anatomical teaching model of the nervous system of the goat (thoracic region from 9 to 12 thoracic vertebrae) (ventral view) showing Truncus sympathicus (ts); Ramus communicans cum truncus sympathicus (rcts); Nervi spinales thoracici (nt) and Vertebrae thoracicae (vt).

D. A photomacrograph of plastinated anatomical teaching model of the nervous system of the goat after opening the vertebral column (fixed on a wooden plate) (lumbar \& sacral regions from 12 thoracic to last caudal vertebrae) (dorsal view) showing Medulla spinalis (msp); N. spinalis lumbalis I (nl I); N. spinalis lumbalis II (nl II); N. spinalis lumbalis III (nl III); N. femoralis (2); N. obturatorius (1); N. ischiadicus (3) and N. pudendus (np) 


\section{Plate (4)}
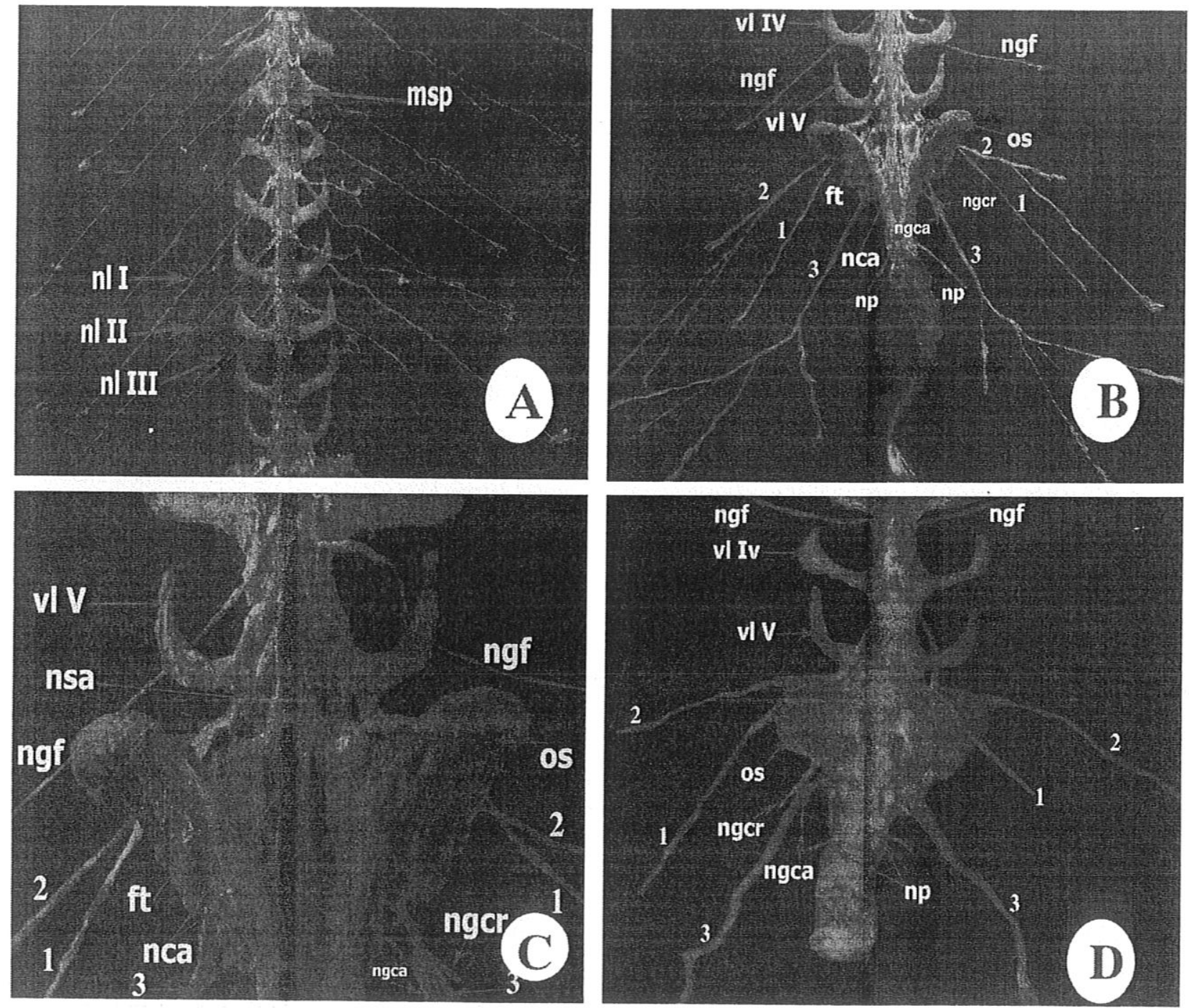

A. A photomacrograph of plastinated anatomical teaching model of the nervous system of the goat after opening the vertebral column (fixed on a wooden plate) (lumbar region from 12 thoracic to 6 lumbar vertebrae) (dorsal view) showing Medulla spinalis (msp); N. spinalis lumbalis I or iliohypogastricus (nl I); N. spinalis lumbalis II or ilioinguinalis (nl II) and N. spinalis lumbalis III (nl III).

B. A photomacrograph of plastinated anatomical teaching model of the nervous system of the goat after opening the vertebral column (fixed on a wooden plate) (lumbar \& sacral regions from 5 lumbar to last caudal vertebrae) (dorsal view) showing Ramus ventralis nervi lumbalis III and IV or N. genitofemoralis (ngf); N. femoralis (2);N. obturatorius (1); N. ischiadicus (3); N. glutaeus cranialis (ngcr); N. glutaeus caudalis (ngca); N. pudendus (np); Filum terminale (ft); Nn. caudales (nca); Vertebra lumalis IV (vl IV); Vertebra lumbalis V (vl V) and Os sacrum (os).

C. A photomacrograph of plastinated anatomical teaching model of the nervous system of the goat after opening the vertebral column (fixed on a wooden plate) (lumbar \& sacral regions from 6 lumbar to last sacral vertebrae) (dorsal view) Showing Ramus ventralis nervi lumbalis III and IV or N. genitofemoralis (ngf); N. femoralis (2); N. obturatorius (1); N. ischiadicus (3); N. glutaeus cranialis (ngcr); N. glutaeus caudalis (ngca); Filum terminale (ft); Nn. sacrales (nsa); Nn. caudales (nca); Vertebra lumbalis V (vl V) and Os sacrum (os).

D. A photomacrograph of plastinated anatomical teaching model of the nervous system of the goat (lumbar \& sacral regions from 5 lumbar to last caudal vertebrae) (ventral view) Showing Ramus ventralis nervi lumbalis III and IV or N. genitofemoralis (ngf); N. femoralis (2); N. obturatorius (1); N. ischiadicus (3); N. glutaeus cranialis (ngcr); N. glutaeus caudalis (ngca); N. pudendus (np); Vertebra lumalis IV (vl IV); Vertebra lumbalis V (vl V) and Os sacrum (os). 


\section{DISCUSSION}

Recently the pattern of plastinated nervous specimens are used for undergraduate medical students, X-rays technicians and physiotherapists as well as for postgraduate teaching of radiologists and neurosurgeons, particularly, how take training of how to approach the epidural space in epidural anesthesia. Thus, plastination has become an important teaching tool.

It had been reported that, regular exposure of technicians of anatomy, histology and histopathology to formaldehyde gas causes serious health hazards.

Although the dissected formalized cadaver remains the most powerful means of presenting and learning anatomy as a dynamic basis for solving problems as anatomy in basic surgical teaching, however the need of clean healthy specimens is desirable (12).

Plastinated organs, as teaching aids, offer advantages over models and organs preserved in formaldehyde (the traditional method), because they are well preserved, dry and odorless. So plastination provides an excellent tool for teaching anatomy $(13,14)$.

The most important finding of the present study is the investigation of the basic structures of the central nervous in interconnections with neurophysiology, .. neurohistology and neurosurgery, to be more familiar and desirable for students. The latter view was the same of (1). In general, the morphological and physical characters of plastinated specimens are excellent to study topographic and clinical anatomy. In addition, numerous advantages were noted; they were much more accurate than synthetic modules, safer for handling, easily stored, odorless and have natural look. These results are in agreement with (15).

However, in contrast with (15), the plastinated specimens were not expensive as such preparations were durable. But agree with him in plastinated neuroanatomical specimens had minimal shrinkage and distortion with their colours close to natural colours.
Conus medullaris of the goat Medulla spinalis was terminated at the first sacral vertebra or between the first and the second sacral vertebrae, this similar with (16). After plastination, it became between last lumbar and first sacral one or just before the first sacral vertebra.

This study revealed that the process of preparation of an anatomical teaching model of Medulla spinalis passes through many steps as mentioned previously by (6). An additional step, It was fixation of plastinated anatomical model by wax and plastic fixers to a painted wooden plate.

The plastinated Medulla spinalis and its plexuses brachialis et lumbosacralis had desirable texture and little difference in its colour. These results were similar to those mentioned by (2).

The present investigation showed an excellent specimen for display in practical anatomical classes which enable students to better understand different origins and formation of plexuses brachialis et lumbosacralis. The different roots and branches of both plexuses were similar to normal formalized samples (16). However the plastinated Nervi spinales and its roots were much firmer and clear than formalized one, some what flexible and easily handled. In this model, students could easily recognize the numbers of nerves of each segment of the spinal cord.

In the same line with (17), the knowledge of regional anatomy had an important role in general surgical practice, such the plastinated cauda equina of the goat could be useful in studying and determining the anatomical relations and the extension of epidural space in goat, thus is helpful in posterior epidural anesthesia in surgical operations.

Concerning the new applications in recent years, plastinated samples will facilitate the understanding and imagination of complex branches such as neuroanatomy, as plastinated models are considered one of the best learning aids, the latter agreed with $(18,19)$. 
Plastination has proven to be the best method to preserve important anatomic and surgical details of the nervous system; however, there are also other applications in pathology and in forensic science (20).

Plastination in teaching neuroanatomy is very useful for practical classes and suitable for handling by students. This is due to allowed long use of the specimens where compared with formalin preservation. So conclusion, plastination technique positively influence the degree of satisfaction of the students, so most of the students preferred plastinated specimens for studying neuroanatomy.

Analysis of variance was used to determine whether there is a relationship between the type of formalin and plastination preservation techniques was investigated, the mean obtained for the plastination technique was higher than that for formalin technique.

Plastinated specimens are further used to produce a three dimensional computer images that are useful in computer-based learning program for freshmen and second year veterinary students.

\section{REFERENCES}

1.Holladay S D and Hudson, L.C. (1989): Use of plastinated brains in teaching neuroanatomy at the North Carolina state university, college of veterinary medicine. Department of Anatomy, Physiological Sciences, and Radiology. J Int Soc Plastination, Vol 3(1):15-17.

2.Barnes $T \quad R \quad$ (1990): Plastination of neuroanatomical and anatomical specimens. College of osteopathic medicine. Ohio university Athens, Ohio. Published by David Kope Instuments. Tujunga. California. No.26.1-4.
3.Grondin $G$ and Olry $R$ (1996): Current Plastination Index.. Publication of the International Society for Plastination. TroisRi-Vieres, Universite du Quebec.102-141.

4Jones $R S$ (2008): Combining local and general anathesia for better pain relief in dogs and cats. 3rd Ed. W.B. Saunders Company. 120-140.

5.Riepertinger $A$ (1988): Fixation of Brain for Plastination: Special considerations. J Int Soc Plastination 2:8-12.

6.Riepertinger $A$ (1989):Plastination of the brain with attached spinal cord. J Int Soc Plastination, Institute of Pathology, City Hospital München-Schwabing. West Germany. Vol 3:22-28.

7.Priya $K C N$, Lama $S$ and Magar A(2007): Plastination - an unrevealed art in the medical science. J Int Soc Plastination 2:812. 5(1). Issue 17. 139-141.

8.Weiglein, A.H. and Henry, R.W. (1993): Curing (Hardening, Polymerization) of the polymer-Biodur S10. Journal of International Society for Plastination 7: 3235.

9.Snedecor $G W$ and Cochran $W G$ (1982): Statistical methods. 6th edition Iowa State University Press Ames, U. S. A. 123-130.

10. Nomina Anatomica Veterinaria (2012): 5th edition. Prepared by the International Committee on Veterinary Gross Anatomical Nomenclature (I.C.V.G.A.N.). Authorized by the General Assembly of the World Association of Veterinary Anatomists (W.A.V.A.) Knoxville, TN (U.S.A.) 2003. Published by the Editorial Committee Hannover (Germany), Columbia, MO (U.S.A.), Ghent (Belgium), Sapporo (Japan). 118-135.

11.Latorre RM, García-Sanz MP, Moreno M, Hernández F, Gil F, López $O$, Ayala MD, Ramírez $G$ Vázquez JM, Arencibia $A$ and Henry RW (2007): How useful is plastination in learning anatomy? Department of Veterinary Anatomy, University of Murcia, Campus de Espinardo, Spain. latorre@um.es. J. Vet. Med. Educ. 34 (2).172-6. 
12.Older $J$ (2004): Anatomy: a must for teaching the next generation. Surgeon, Apr; 2(2): 79-90.

13.Weiglein A $H$ (1999): Plastination - A teaching and research tool. Journal of International Society for Plastination 14 (2): 10.

14.Frenz $C$, Fritsch $H$ and Hoch $J$ (2000): Plastination histologic investigations on the inserting pars terminalis aponeurosis dorsalis of three-sectioned fingers. Anat. Anz. 182(1). 69-73.

15.Nicaise M, Simoens PS and Lauwers $H$ (1994): Demonstration of plastinated organs used in teaching anatomy. Anatomicia, Histologia, Embryologia 23(1) march: 78 .

16.Getty $R$ (1975) : Anatomy of domestic animals .5th Ed. W.B. Saunders Company. Philadelphia. London. Toronto. 1787-2031.
17.Alpàr A, Klàmàn $M L$ and Potonay $L$ (1999): Local flaps for fingertip injuriesPlastinated hand specimens in surgery education. Journal of international society for plastination 14(2): 35 .

18.Soliman Kh Z, Anis H, Khidr IMS, Abdel Aziz SE, Basset Aly AE and El-Ghazali HM (2008): Plastination of The Cerebellum of Goat. $9^{\text {th }}$ Vet. Med. Zag. Conference (2022 August). Port-Said. A.R. Egypt. 672767.

19.Basset Aly AE, Mervat Konsowa, Elnady $F$, Abdel Aziz SE and SolimanKh (2006): Sheet plastination of The brain for veterinary mecicine educational technology. of Goat. $8^{\text {th }}$ Sci.Vet. Med. Zag. Conference (31Aug-3 Sept). Hurghada. 462-468.

20.على اللاين عبد الباسط على، على عبد الخالق السواد

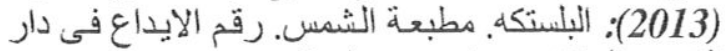
الكتب و الؤثائق بيغداد 2195 لسنة 2013.

\section{الملخص العربي \\ استخدام تقنية البلستكه للضفيرتين العضدية والقطنية العجزية وذنب الفرس في تعليم الجهاز العصبي في الماعز}

على الدين عبد الباسط على، عاطف عبل العزيز السيد سليم ، شريف خيري عبد المعطى محمد

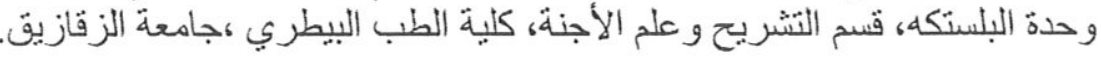

أصبحت البلستكه الخاصة بالجهاز العصبي وسيلة مومة لتدريس التشريح العصبي. أبضا من المعكن استخدام

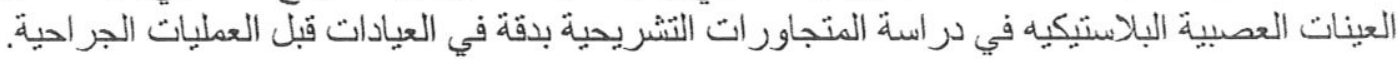

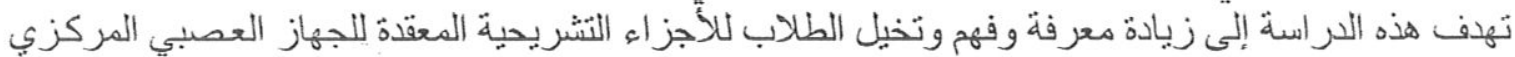

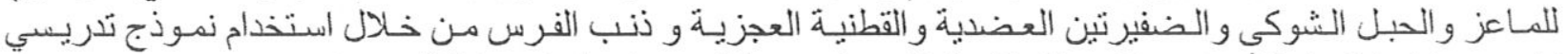

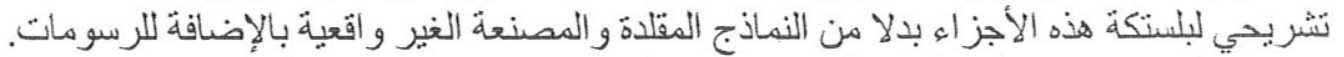

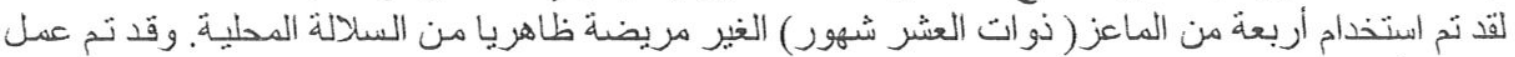

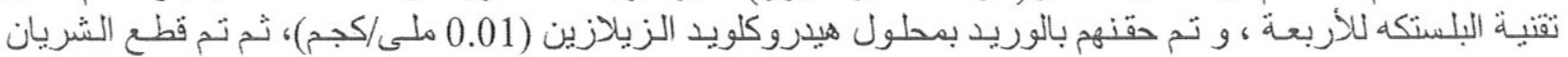

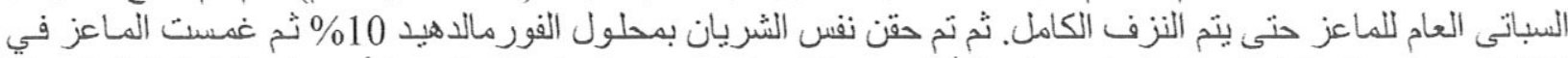

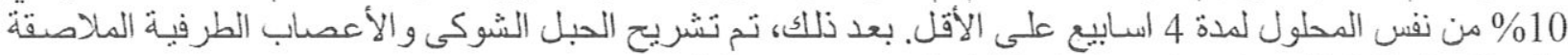

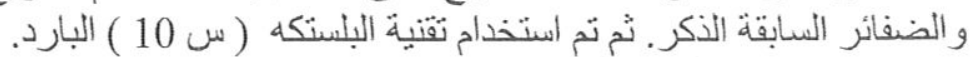
تعتبر قيمهة هذا البحثت من استخدام نموذج تشريحي باستخدام طرق البلستكه هو لتحسبن تدريس التشريح

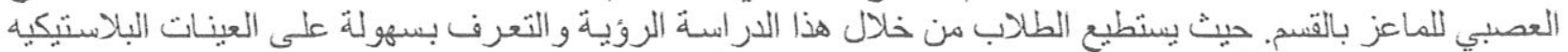

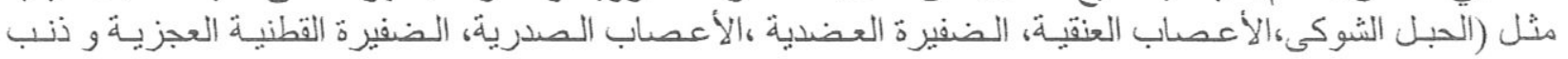

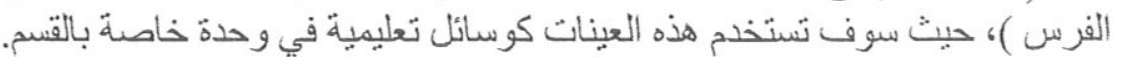

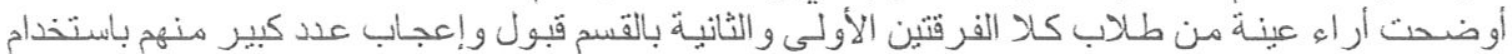

طريقة البلستكه في الدروس العملية والبعض فضل الدمج بين الطريقتين التقليدية باستخدام الفورمالين وطريقة البلستكه. 